начальник відділу організації наукової роботи Луганського державного університету внутрішніх справ імені

Е.О. Дідоренка (м. Сєвєродонецььк, Україна)

Пеи Д. М.

судовий експерт сектору досліджень зброї відділу криміналістичних видів досліджень Луганського науководослідного експертно-криміналістичного иеентру МВС України (м. Рубіжне, Украӥна)

\title{
КРИМІНАЛІСТИЧНЕ ДОСЛІДЖЕННЯ КАРАБІНУ МИСЛИВСЬКОГО «НОWА 1500 HOGUE SCOPE»
}

У статті наведено конструктивні особливості та характеристики карабіна мисливського «Howa 1500 Hogue Sсоре», а також результати дослідження слідів на кулях та гільзах. Виокремлено деталі, які утворюють сліди на гільзах та кулях патронів, стріляних 3 цього карабіна, та $є$ такими, що дають змогу провести ідентифікацію.

Подано описання експериментально отриманих слідів на мішенях з різних типів тканин з різних дистанщій. Систематизовано особливості слідів, що можуть бути використані як критерії діагностики як самої зброї, так і факту й умов іï застосування.

Ключові слова: варіативність, гільзи, досудове розслідування, ідентифікаційний період, ідентифікація, кулі, мисливська нарізна вогнепальна зброя, сліди, стрілецька вогнепальна зброя, судова балістика.

Постановка проблеми. Останніми роками в Україні спостерігається постійне зростання числа зареєстрованих злочинів, пов'язаних із незаконним поводженням з вогнепальною зброєю та бойовими припасами.

Якщо 2013 р. зареєстровано 6929 злочинів, передбачених ст. 263 КК України, то 2014 р. - 7228; 2015 р. - 7409; 2016 р. - 6307; 2017 р. - 8002; 2018 р. - 7466. Поряд із цим зростає число кримінальних правопорушень, учинених із застосуванням вогнепальної зброї. Тому про нормалізацію ситуації ще не йдеться. Ефективність досудового розслідування кримінальних проваджень зазначеної категорії безпосередньо залежить від якості ідентифікаційних, діагностичних та ситуаційних судово-балістичних та комплексних експертиз.

Результативність, наприклад, ідентифікаційних експертиз складає в середньому 27\% від числа виконаних, і цей показник не варто вважати задовільним.

Якість, переконливість, наочність експертного висновку пов'язані 3 рівнем наукового та методичного забезпечення процесу експертного дослідження. Тому в число обов' язкових пізнавальних і практичних підзадач, наприклад, типової методики ідентифікації має бути включено:

- матеріальне та інформаційно-довідкове забезпечення;

- визначення властивостей порівнюваних об'єктів у спосіб аналізу ідентифікаційних ознак;

- виявлення збігів та відмінностей через порівняння властивостей ототожнюваних об'єктів;

(C) Бондар В. С.,

Пец Д. М. 2019 
- сукупна оцінка виявлених збігів та відмінностей, формулювання висновків.

Однією з розповсюджених у незаконному обігу моделей вогнепальної зброї є мисливський карабін Howa Hogue. Ця модель зброї має надійну конструкцію й часто використовується з нештатними патронами. Крім того, актуальність криміналістичного дослідження цього зразка зброї зумовлена:

- велике розповсюдження вказаного зразка зброї через надійність, якість, ергономічність, що приваблює покупців та власників;

- велика відстань, з якої можливе проведення прицільних пострілів (до 1000 метрів і більше) через потужність патронів «.30-06 Spr» тощо;

- відсутність достатньої кількості довідкової інформації, потрібної для методичного забезпечення проведення судово-балістичних та комплексних досліджень 3 ідентифікації зброї такого зразка під час досудового розслідування кримінальних проваджень, відкритих за фактами іï застосування, що викликає складнощі при вирішенні питання про модель зброї, з якої могли бути стріляні виявлені гільзи та кулі, а також чи єдиний екземпляр зброї, з якої зроблено постріли.

Аналіз останніх досліджень і публікацій. Розробці питань ідентифікації вогнепальної зброї присвячені роботи В. С. Бергера [3], Д. Ю. Гамова, Б. М. Срмоленка [5], А. В. Кокіна [6; 7; 14], Б. М. Комаринця [8], С. А. Матвієнка [8], І. В. Латишова [1, с. 125-127; 4, с. 24-27], Л. Ф. Савраня, Є. І. Сташенка [15], В. О. Федоренка [13, с. 40-42; 19, с. 56-58; 20, с. 17-24; 21], Б. І. Шевченка [22] та інших учених і практиків [11, с. 497-506; 12, с. 89-91], які фактично сформували систему сучасних наукових уявлень у цій галузі. Тому сьогодні без урахування та аналітичного розгляду їх наукового внеску не може обійтися жодна серйозна праця із зазначеної проблеми.

Водночас треба визнати, що у вітчизняній спеціальній юридичній літературі проблеми криміналістичного дослідження окремих зразків нарізної мисливської вогнепальної зброї в комплексі не розглядали.

Формування цілей. Метою статті $є$ вивчення ознак вхідних вогнепальних пошкоджень одягу з мисливського карабіна «Howa 1500 Hogue Scope», завданих пострілами штатного патрона в межах різних зон (відстаней) близької дистанції. Вивчення та систематизація інформації про механізм утворення слідів на кулях та гільзах, стріляних зі зброї зазначеної моделі; виявлення особливостей, пов'язаних 3 ідентифікаційним та діагностичним дослідженням сучасних зразків нарізної мисливської зброї для підвищення ефективності цих досліджень під час виявлення та досудового розслідування кримінальних правопорушень.

Виклад основного матеріалу. Мисливський карабін «Howa 1500 Hogue Sсоре» призначений для високоточної стрільби на середніх та великих дистанціях. Створений компанією «Howa Machinery Company Ltd» 1979 року. Виробляють у Японії. Розроблений під патрони калібру «.30-06 Spr», ефективні для ураження цілі під час полювання, а також спортивної стрільби.

Карабін мисливський складається з основних частин та деталей: ствол і ресивер у зборі; затвор; спусковий механізм; запобіжник; спускова скоба; магазин; ложе. Ударно-спусковий механізм ударникового типу дає змогу 
вести тільки одиночну стрільбу. Магазин постійний коробчастий розрахований на п'ять патронів з паралельним розташуванням патронів.

При пострілі порохові гази слідують за кулею, що спрямовується через ствол. Перезаряджання при стрільбі здійснюється вручну в спосіб повороту та відведення в крайнє задане положення затвора, що поздовжньо ковзає. Ствол має правонахильні нарізи каналу ствола. Особливістю видалення стріляних з карабіна гільз є зачеп, змонтований у затворі.

Для отримання експериментальних гільз та куль щодо вивчення слідів від частин зброї здійснювалась експериментальна стрільба у волоконний кулеуловлювач. Гільзи та кулі, отримані під час експерименту, збирали та досліджували неозброєним оком, а також під мікроскопом «МБС-10» i порівняльним мікроскопом «МСК-1».

Найбільш важливими деталями, які утворюють сліди на гільзах та кулях патронів, стріляних 3 карабіна мисливського «Ноwa 1500 Hogue Scope», та такими, що дають змогу провести групову та індивідуальну ідентифікацію є: а) бійок; б) зачеп викидача; в) патронний упор; г) відбивач.

Сліди на частинах патронів, утворені іншими деталями зброї, виражені слабко та є малоінформативними.

Розташування слідів на гільзі зумовлено конструктивними особливостями затвора.

Зачеп викидача в затворі розташовується в лівій верхній частині затвора (10-11 годин умовного циферблату). Відбивач змонтований у затворі. Виступ відбивача розташовується в правій верхній частині затвору (2 години). Вищезазначені деталі утворюють такі кутові розміри (рис. 1):

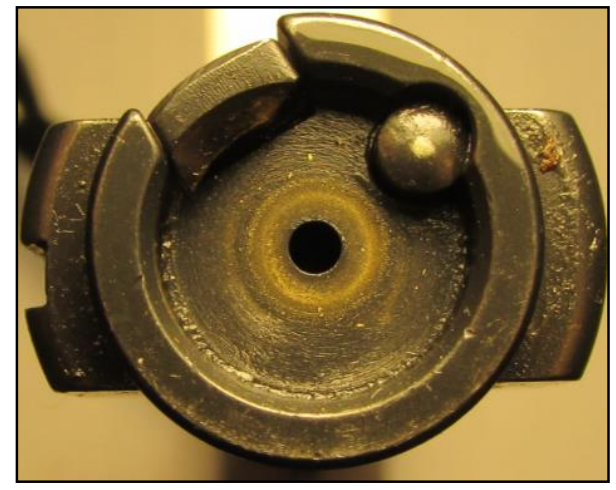

Рис. 1.Чашка затвору карабіна «Howa 1500 Hogue Scope».

1) слідоутворювальна поверхня зачепа викидача за окружністю складає 55 градусів;

2) кут між верхньою гранню зачепа викидача та вершиною виступу відбивача складає 80 градусів. 
Штатними для карабіна мисливського «Howa 1500 Hogue Scope» $€$ патрони калібру «.30-06 Spr», розроблені в США в першій половині XX сторіччя 1906 року на заміну патрона «.30-03.» зразка 1903 року. Конструкція цих патронів являє собою гільзу, капсуль, пороховий заряд та кулю.

Патрон є унітарним. Заряд складається з пороху марки Lovex S065 (гранули сірого кольору, циліндричної форми).

Капсуль складається з ковпачка (чашечки), вибухової суміші, ковадла, початкового отвору. Свинцеве осердя не тільки надає кулі потрібної маси, але й забезпечує її обтюрацію при врізанні в нарізи каналу ствола. Куля патрона оболонкова, складається зі свинцевого осердя та балістичного ковпачка.

Швидкість кулі складає 850 м/с. Дульна енергія - порядку 4309 Дж.

Гільзи патрона «.30-06 Spr», стріляні 3 карабіна мисливського «Howa 1500 Hogue Sсоре», мають такі особливості:

1) слід від бойка ударника визначається в центрі капсуля рельєфної вм' ятини кола діаметром 1,9 мм;

2) слід від зачепа викидача визначається на гільзи патрона калібром «.30-06» у вигляді групи трас шириною 2,1 мм;

3) слід відбивача визначається на денці гільзи патрона калібром «.30-06» у вигляді овального сліду.

На кулях, стріляних з мисливського карабіна «Howa 1500 Hogue Scope» є такі сліди:

1) групи виражених слідів від полів нарізів, а саме бойової та холостої грані ствола $з$ правостороннім нахилом 7 градусів та шириною 1,3 мм, які утворюються при поступально обертальному проходженні кулі за каналом ствола;

2) сліди у вигляді групи трас, які складаються з валиків та борозенок, вузьким кінцем направлених до донної частини кулі, що утворюються при врізанні кулі в поля нарізів;

3) рельєфний слід кільцевого обтиску, що збереглися;

4) копчення ведучої частини кулі, локалізоване із зовнішнього боку слідів від холостих та бойових граней полів нарізів.

Для вивчення характеру та особливостей пошкоджень, утворених пострілами 3 мисливського карабіна «Howa 1500 Hogue Scope», було проведено серію експериментальних одиночних пострілів. Як мішені використовували тканину NYCO Rip-Stop (50\% нейлон, 50\% хлопок). Мішені почергово укріплювалися на стандартному кулеуловлювачі зі щільним наповнювачем - кевларовим волокном (відповідно до методики проведення судово-балістичних експертиз).

Постріли здійснювалися «упритул», 100 см, 300 см, обраних як середні значення зон дії на уражувані об'єкти факторів пострілу. Загалом було проведено більше 15 пострілів.

На кожній мішені при кожній дистанції пострілу вимірювалися два взаємно перпендикулярних параметри зон відкладень супутніх продуктів пострілу, а їх середне арифметичне приймалося за усереднені розміри. Виявлення особливостей ознак близького пострілу з карабіна Howa 1500 
Hogue Scope» здійснювалося візуальними методами та з використанням методик, прийнятих у сучасній судово-балістичній експертизі.

Візуальним дослідженням мішеней установлено, що при пострілах упритул пошкодження мають овальну форму максимальними розмірами 213 мм на 71 мм, 3 розволокненням, 3 округлими дефектами в центрі діаметром 25 мм. На прилеглих до країв дефектів тканин ділянках візуально визначаються гомогенні нашарування сірого кольору 3 убуванням від центру до периферії на ділянках радіусом до 50 мм, зі зміщенням дещо вліво та до низу, а відповідно в зоні контакту мушки - сектороподібні (вершиною до центру) ділянки доволі інтенсивного нашарування тієї ж речовини гомогенного характеру, волокна тканини ввігнуті в середину пошкодження та оплавлені.

При пострілах 3 відстані 300 см пошкодження мають круглу форму, максимальними розмірами 6,5 мм на 6,4 мм з гомогенним нашаруванням у вигляді пояска обтирання чорного кольору, волокна тканини ввігнуті в середину пошкодження та оплавлені.

При дослідженні експериментальних тканин контактно-дифузним методом «кольорових відбитків» на сурму та мідь за загальноприйнятою методикою визначається наявність на всіх контактограмах слідів, що характерні слідам пострілу.

Металізація міддю при пострілах упритул представлена дифузноточково з інтенсивним суцільним зафарбленням у радіусі до 50 мм. Відкладення сурми при пострілах упритул представлені у вигляді гомогенного нашарування сірого кольору 3 убуванням від центру до периферії на ділянках радіусом до 50 мм. Отже, під час проведення криміналістичного дослідження слідів застосування карабіна мисливського «Howa 1500 Hogue Scope» установлено:

1. Основними особливостями карабіна мисливського «Howa 1500 Hogue Sсоре», які здійснюють суттєвий вплив на формування вхідних вогнепальних пошкоджень, а також на вихід, розповсюдження, уражуючі властивості супутніх продуктів пострілу, а відповідно й на картину їх відкладення на мішені є:

1.При пострілі 3 дистанції 300 мм неозброєним оком та при застосуванні мікроскопа «МБС-10» можемо спостерігати два явища. Перше це поясок обтирання на тканині та друге явище «феномен Виноградова». Цей факт пояснюється тим, що під час польоту кулі попереду неї утворюється стиснене повітря, а за кулею - виряджене, у якому за інерцією супроводжує кулю залишкова кількість кіптяви. При влучанні в перешкоду кулі та ії проникненні через першу перешкоду балістичні хвилі руйнуються, а ті, що містяться в закульовому просторі, кіптява відкладається на другій перешкоді навколо вхідного отвору у вигляді променів, що розходяться.

2. Основними особливостями штатних мисливських патронів до карабіна «Howa 1500 Hogue Scope» є те, що патрон відноситься до калібрів універсального призначення, який може застосовуватися по всьому світу при полюванні на будь-яку дичину. Особливість патронів «.30-06» є його 
оптимальні балістичні якості, що задовольняють вимоги як мисливців, так і спортсменів. Властива патрону висока точність поєднується 3 потужністю, досягає 4000 Дж; з прийнятною віддачею й поліпшеним використанням порохового заряду. Ці якості привели до застосування патронів «.30-06» у всіх типах мисливської зброї, до того ж ієрархічну сходинку дотепер займає зброя із затвором, що поздовжньо ковзає затвором.

3. Особливості слідів, які спостерігаються на гільзах, стріляних 3 карабіна мисливського, такі:

- динамічний слід від зачепа викидача відобразився в правій верхній частині денця гільзи у вигляді групи трас, які розташовані на денці гільзи та його фланці.

- статичний слід від бійка ударника, що відобразився в центрі капсуля у вигляді рельєфного поглиблення круглої форми.

- слід відбивача відобразився в лівій верхній частині денця гільзи у вигляді рельєфного поглиблення овальної форми.

- статичний слід від чашки затвора й отвір для бійка.

4. Для стрільби у вищеописаному карабіні «Howa 1500 Hogue Scope» використовуються мисливські патрони «.30-06 Spr» зі свинцевим осердям та іноді з балістичним ковпачком. Ці конструктивні особливості в поєднанні 3 великою швидкістю призводять до того, що кулі при влучанні в перешкоду деформуються, балістичний ковпачок виконує роль клину, що пришвидшує розкривання кулі при потраплянні в перешкоду, а іноді й до ії повної руйнації, що ускладнює ії дальше дослідження.

5. Особливості пошкоджень предметів одягу такі: при пострілі 3 мисливського карабіна «Howa 1500 Hogue Scope» упритул дуже яскраво відображаються сліди, а саме великий діаметр вхідного отвору, характерний хрестоподібний розрив. Краї тканини зазнають термічного впливу та опалення, волокна ввігнуті в середину, численні розволокнення та на ділянках візуально визначаються гомогенні нашарування сірого кольору зі зміщенням від центру до периферії, зі зміщенням дещо вліво та до низу.

Висновки. Виявлені особливості можуть бути використані як критерії для диференціальної діагностики як самої зброї, так і факту та умов іï застосування. Інформацію про розглянуту в статті модель мисливської нарізної вогнепальної зброї може бути внесено в методику діагностичного та ідентифікаційного дослідження нарізної вогнепальної зброї за слідами на стріляних кулях та гільзах.

\section{Використані джерела:}

1. Бондарь В.С. Общеметодические проблемы криминалистического исследования огнестрельного оружия и следов его применения. Известия Саратовского университета. Новая серия. Серия Экономика. Управление. Право. Том 14. 2014. № 1-2. C. 234-238.

2. Ермоленко Б. Н. Теоретические и методические проблемы судебной баллистики. Киев: Редакционно-издательский отдел МВД УССР, 1976. 152 с. 
3. Кокин А. В. Концептуальные основы криминалистического исследования нарезного огнестрельного оружия по следам на пулях: дис. ... докт. юрид. наук. 12.00.12. Москва., 2015. 388 с.

4. Кокин А. В. Концептуальные основы криминалистического исследования нарезного огнестрельного оружия по следам на пулях. Москва: Издательство «ЩитM», 2013. 191 c.

5. Кокин А. В., Ярмак К. В. Судебная баллистика и судебно-баллистическая экспертиза: учебник. Москва: Московский университет МВД РФ имени В. Я. Кикотя, 2018. 354 c.

6. Кокин А. В. Теория и методические основы исследования нарезного огнестрельного оружия по следам на пулях. Москва: Издательство «Юрлитинформ», 2010.352 c.

7. Колесник В. А., Гора I. В. Криміналістика в протидії незаконному використанню вибухових пристроїв, вогнепальної зброї та обігу наркотиків: навч. посіб. Київ: Юрінком Інтер, 2017. 400 с.

8. Матвієнко С. А. Щодо проблемних питань проведення судовобалістичної експертизи з ідентифікації мисливської нарізної зброї на стадії досудового розслідування. Науковий вісник Дніпропетровського державного університету внутрішніх справ. 2015. № 1. С. 497-506.

9. Матвієнко С. А. Особливості криміналістичного дослідження сучасних зразків нарізної мисливської вогнепальної зброї виробництва Італії. Вісник Луганського державного університету внутрішніх справ імені Е. О. Дідоренка. 2016. № 2. C. $230-235$.

10. Ручкин В. А. Современные боеприпасы в криминальной практике: тенденции их развития. Вестник Волгоградской академии МВД РФ. Выпуск 1 (20) 2012 : научно-методический журнал. Волгоград : ВА МВД России, 2012. С. 219-221.

11. Соколов О. С., Дєда О. О., Лопатюк К. А., Голдинський І. А. Мисливські карабіни під патрони центрального бою та їх сліди на стріляних гільзах. ДНДЕКЦ МВС України. Київ, 2018. 170 с.

12. Федоренко В. А. Актуальные проблемы судебной баллистики: монография. М.: Издательство «Юрлитинформ», 2011. 208 с.

Стаття надійшла до редколегї 26.01.2019

Бондарь В. С., кандидат юридических наук, доцент, начальник отдела организации научной работы Луганского государственного университета внутренних дел имени Э. А. Дидоренко (г. Северодонецк, Украина)

Пец Д. М., судебный эксперт сектора исследований оружия отдела криминалистических видов исследований Луганского научно-исследовательского экспертно-криминалистического центра МВС Украины (г. Рубежное, Украина)

Криминалистическое исследование карабина охотничьего «Howa 1500 Hogue Scope»

В статье приведены конструктивные особенности и характеристики карабина охотничьего «Howa 1500 Hogue Scope» и результаты исследования следов на пулях и гильзах. Выделены детали, образующие следы на гильзах и пулях патронов, стрелянных в данном карабине, позволяющие провести идентификацию.

Представлены описания экспериментально полученных следов на мишенях из разных типов тканей с различных дистанций. 
Систематизированы особенности следов, которые могут быть использованы в качестве критериев диагностики как самого оружия, таки и условий его применения.

Ключевые слова: вариационность, гильзы; досудебное расследование, идентификационный период, идентификация, пули, охотничье нарезное огнестрельное оружие, следы, стрелковое огнестрельное оружие, судебная баллистика.

\section{Bondar V., Pets D. Forensic Investigation of a Hunting Carbine "Howa 1500 Hogue Scope"}

The article presents the design features and characteristics of the hunting rifle "Howa 1500 Hogue Scope" and the results of the study of traces on bullets and cartridges. The parts forming traces on the cartridge cases and bullets of cartridges shot in this carbine, allowing identification are highlighted.

The descriptions of experimentally obtained traces on targets from different types of tissues from different distances are presented. The features of traces that can be used as diagnostic criteria for both the weapon itself and the conditions of its use are systematized.

It has been established that the peculiarities of damage to clothing items are as follows: when firing a hunting carbine "Howa 1500 Hogue Scope", traces are very clearly reflected in the focus, namely the large diameter of the inlet, the characteristic cruciform gap. The edges of the fabric experience thermal impact and melting, the fibers are concave inwards, numerous fibers develop and homogeneous layers of gray color are visually determined at sites with a shift from the center to the periphery, with a shift slightly to the left and down.

It is substantiated that the identified features can be used as criteria for the differential diagnosis of both the weapon itself and the fact and conditions of its use. The information on the model of a hunting rifle firearm considered in the article can be entered into the diagnostic and identification research methodology for rifled firearms in the footsteps of bullets and cartridges.

Key words: variation, cartridges, pre-trial investigation, the identification period, identification, bullets, laser marking, signs, traces, small firearms, forensic ballistics.

\section{ОПЕРАТИВНИЙ ПОШУК ПЕРВИННОЇ ОПЕРАТИВНО- РОЗШУКОВОЇ ІНФОРМАЦІЇ ПІДРОЗДІЛАМИ КРИМІНАЛЬНОЇ ПОЛІЦІї: ЗМІСТ ПОНЯТТЯ}

Статтю присвячено вдосконаленню термінологічного наповнення змісту поняття «оперативний пошук первинної оперативно-розшукової інформації підрозділами Національної поліції України». Визначено, що сучасна теорії ОРД характеризується тривалою та жвавою дискусією щодо визначення як самого поняття «оперативний пошук», так і похідного від нього; проаналізовано наявні 